\title{
JOURNAL OF THE MARINE BIOLOGICAL ASSOCIATION
}

\section{INSTRUCTIONS FOR THE PREPARATION OF MANUSCRIPTS}

Editorial Policy. The JMBA publishes original research papers on all aspects of marine biology and oceanography which have not been published, and are not under consideration for publication, elsewhere.

General. Papers should be written in clear, succinct English and sentences must not start with an abbreviation. They should not normally exceed 20 printed pages. Acronyms must be specified in full on their first occurrence and SI units should be used. Only the scientific names of species should be italicized, and their first mention should be followed by the authority except where reference is made to a work in which the authority appears.

A total of three copies of the typescript should be provided, double-spaced throughout, on one side of A4 paper. Tables and legends for illustrations should be typed separately at the end of the manuscript. All pages should be numbered serially (title, main text, acknowledgements, references, figure legends, tables). Short communications should not exceed four printed pages, including tables and illustrations, and must start with an abstract but not otherwise divided into sections.

If there is a particular reason why rapid publications is desirable this should be stated with the revised manuscript.

Fifty reprints will be provided free of charge and up to 200 extra copies may be purchased if ordered when the proofs are returned.

Title. Each paper must have a unique title and should be kept as short as possible (maximum 18 words), and if specific names are included the authority should be omitted.

Abstract. Each paper (including short communications) must start with a brief abstract summarizing the main results and conclusions of the work, and such other information as to make it suitable for publication without change in abstracting journals.

References. References should be kept to an essential minimum and must be listed alphabetically at the end of the paper. Titles of journals are given in full and references to books should include the place of publication and publisher.

Examples:

Goldberg, E.D., 1965. Minor elements in sea water. In Chemical oceanography, vol. 1 (ed. J.P. Riley and

G. Skirrow), pp. 163-196. New York: Academic Press.

Marshall, S.M., Nicholls, A.G. \& Orr, A.P., 1939. On the growth and feeding of young herring in the

Clyde. Journal of the Marine Biological Association of the United Kingdom, 23, 427-455.

Russell, F.S. \& Yonge, C.M., 1928. The seas. London: Frederick Warne.

Figures. Figures should be in black ink on white paper no larger than A4. Figures will normally be reduced to one-third of a page on average and the maximum size for a figure or photograph after reduction is $134 \times 200 \mathrm{~mm}$, including legend. Lettering, numerals etc. should be Helvetica 8 point after reduction. Half-tone photographs will be reproduced in the text pages and should be supplied as three sets of glossy prints with suitable labelling on the originals. Sizes should be indicated by a scale line on the print. All illustrations, including photographs, are numbered in Arabic numerals. Detailed instructions for figure preparation will be provided with the manuscript for revision and will be returned if they do not conform to $J M B A$ publication style. Colour illustrations can be included but only at the author's expense (as a rough guide, from $£ 1000$ per page).

Tables. Tables should be numbered in Arabic numerals, and given a concise heading. Formatting instructions will be sent with the manuscript for revision.

Word-processor discs. All manuscripts should be provided on a Macintosh or IBM-type disc after the paper has been accepted. Detailed instructions for revisions and format will be provided with the manuscript for revision. Authors should ensure that the disc version and hard copy are identical.

Authors are requested to see that their manuscripts are in finished form and completely ready for publication so that corrections may be reduced to a minimum. Alterations to the text at the proof stage will be charged to the author. 


\section{CBM \\ CAHIERS DE BIOLOGIE MARINE}

Editor: ANDRÉ TOULMOND

Executive Editor: CLAUDE JOUIN-TOULMOND

Editions de la Station Biologique de Roscoff BP 7429682 ROSCOFF Cedex France

\section{CBM}

CAHIERS DE BIOLOGIE MARINE

is a quarterly international journal with

a worldwide distribution, publishing original papers within the general field of marine biology and biological oceanography. Subjects covered include : biodiversity, ecology, ecophysiology, life cycles, development, physiology of reproduction, functional anatomy and fine structure, phylogeny, molecular phylogeny. Reviews on current topics are welcome. Selected papers or abstracts from symposia or workshops can also be considered.
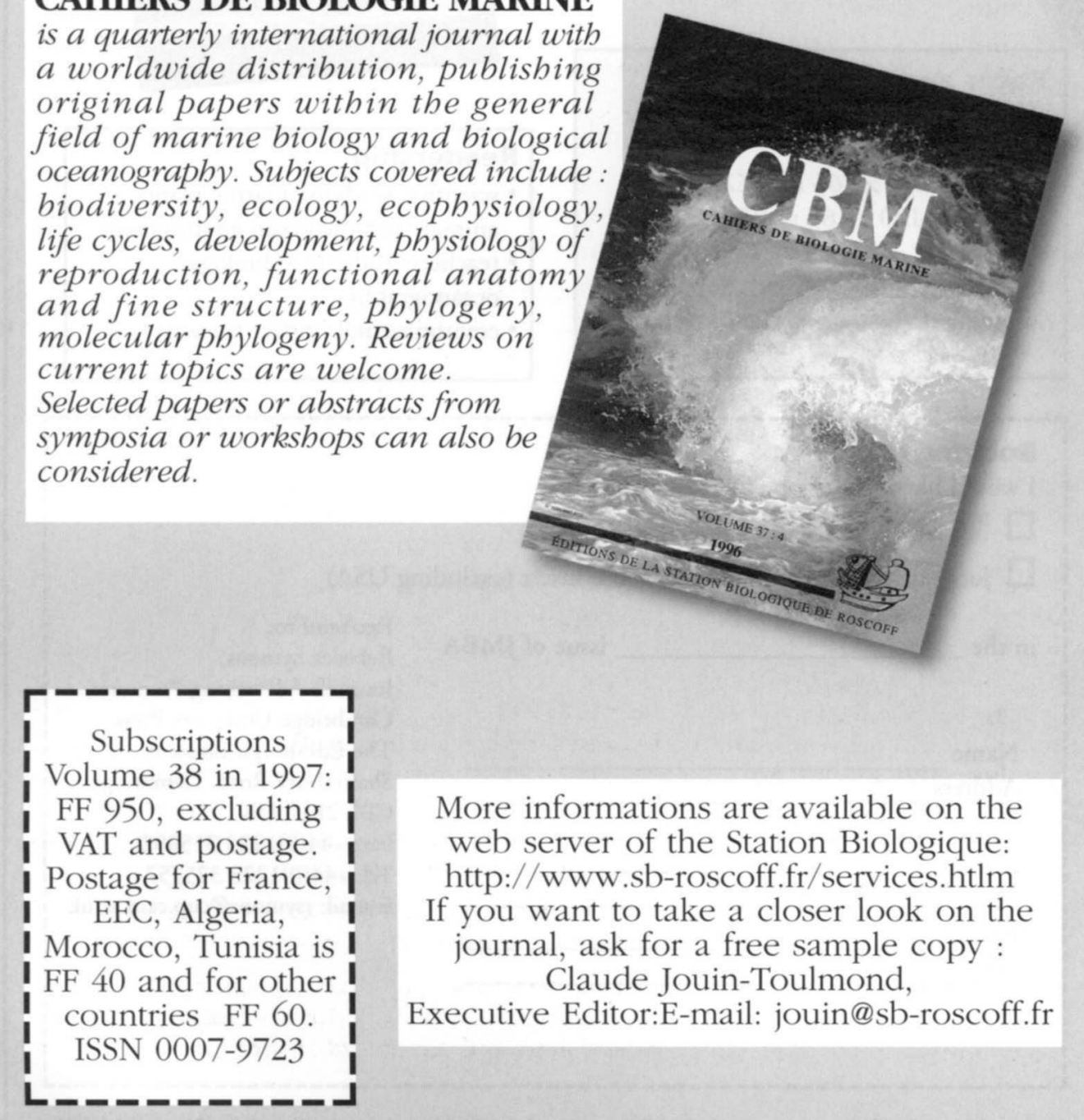

More informations are available on the web server of the Station Biologique: http://www.sb-roscoff.fr/services.htlm If you want to take a closer look on the journal, ask for a free sample copy : Claude Jouin-Toulmond,

Executive Editor:E-mail: jouin@sb-roscoff.fr 


\section{Advertise in JMBA}

Published for the Marine Biological

Association of the United Kingdom, this journal publishes research from workers in many countries on all aspects of marine biology. Subjects covered include: ecological surveys and population studies of oceanic, coastal and shore communities; physiology and experimental biology; taxonomy; morphology and life history of marine animals and plants; and chemical and physical oceanographic work related to the biological environment.

\section{Rates and Data}

Published quarterly in February, May, August and November.

Full page: $250 \times 165 \mathrm{~mm} £ 275 / \$ 440$ Half page: $120 \times 165$ or $250 \times 80 \mathrm{~mm}$ $£ 165 / \$ 320$

Quart. page: $120 \times 80 \mathrm{~mm} £ 165 / \$ 260$ Loose insert/list rental please enquire

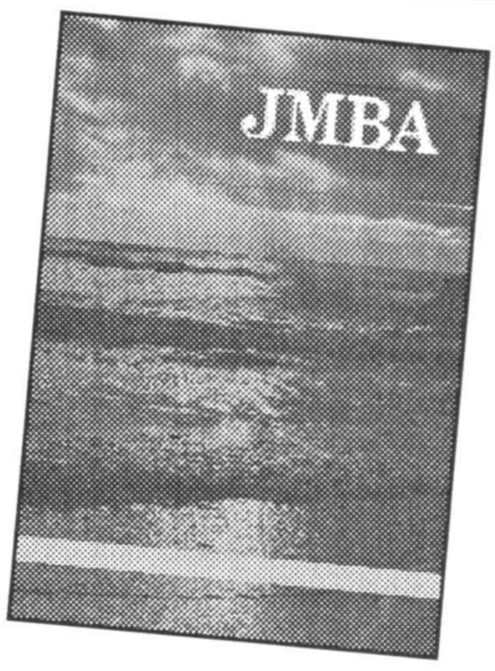

\section{Readership}

- scientists studying marine plants, animals and the ocean environment

- teachers/students of biology/ oceanography

- environmental impact agencies

\section{Bookings}

I would like to book the following space:

$\square$ full page $\square$ half page

$\square$ loose insert (worldwide) $\square$ loose insert (excluding USA)

in the issue of JMBA

Name

Address

Fax

Tel
Fax/send to:

Rebecca Symons,

Journals Advertising Promoter, Cambridge University Press,

The Edinburgh Building, Shaftesbury Road, Cambridge, CB2 2RU, UK

Fax: $+44(0) 1223315052$

Tel: $+44(0) 1223325757$

E-mail: rsymons@cup.cam.ac.uk 
continued from outside back cover

Isani, G., Serra, R., Cattani, O., Cortesi, P. \& Carpene, E. Adenylate energy charge and metallothionein as stress indices in Mytilus galloprovincialis exposed to cadmium and anoxia

Jordana, E., Guillou, M. \& Lumingas, L. J. L. Age and growth of the sea urchin Sphaerechinus granularis in southern Brittany

Deheyn, D., Mallefet, J. \& Jangoux, M. Intraspecific variations of bioluminescence in a polychromatic population of Amphipholis squamata (Echinodermata: Ophiuroidea)

Short Communications:

Parker, A. R.

Richardson, C. A., Kennedy, H., Duarte, C. M. \& Proud, S. V.

Checa, A. G. \& Cadée, G. C.

Jackson, G. D., Buxton, N. G. \& George, M. J. A.

1235

Jereb, P., Stefano, M. di \& Mazzola, A.

1239

Cornwell, C. J., Messenger, J. B. \& Hanlon, R. T.

Madan, J. J. \& Wells, M. J.

Flammang, P. \& Walker, G.

Clarke, M. R. \& Pascoe, P. L.

Anderson, O. R., Rogerson, A. \& Hannah, F. 


\section{JMBA}

JOURNAL OF THE MARINE BIOLOGICAL ASSOCIATION OF THE UNITED KINGDOM VOLUME 77:4 NOVEMBER 1997

\section{CONTENTS}

Bowers, D. G., Tett, P. \& Walne, A. W. A note on seabed irradiance in shallow tidal seas

Tong, S. M. Choanoflagellates in Southampton Water, including the description of three new species

Manley, C. J. \& Shaw, S. R. Geotaxis and phototaxis in Elphidium crispum (Protozoa: Foraminiferida)

Hopwood, J. D., Mann, S. \& Gooday, A. J. The crystallography and possible origin of barium sulphate in deep sea rhizopod protists (Xenophyophorea)

Butler, H. \& Rogerson, A. Consumption rates of six species of marine benthic naked amoebae (Gymnamoebia) from sediments in the Clyde Sea area

Ballard, L. \& Myers, A. Vertical distribution, morphology and diet of Proboscidactyla stellata (Cnidaria: Limnomedusae) in Lough Hyne marine nature reserve, Co. Cork, Ireland

Riemann-Zürneck, K. A hemisessile sea anemone from the Porcupine Abyssal Plain, North Atlantic ocean: losactis vagabunda gen. nov., sp. nov.

Nozais, C., Martin, D., Cha, J.-H., Duchêne, J. C., Charles, F. \& Grémare, A. Dynamics of egg production in Mediterranean populations of the terebellid polychaete Eupolymnia nebulosa

Gambi, M. C., Ramella, L., Sella, G., Protto, P. \& Aldieri, E. Variation in genome size in benthic polychaetes: systematic and ecological relationships

Thiel, M. Reproductive biology of an epibenthic amphipod (Dyopedos monacanthus) with extended parental care

Achituv, Y. \& Yamaguchi, T. Water pumping in the penduculate barnacle Conchoderma auritum

Pinn, E. H., Rogerson, A. \& Atkinson, R. J. A. Microbial flora associated with the digestive system of Upogebia stellata (Crustacea: Decapoda: Thalassinidea)

Wharton, D. N., Jinks, R. N., Herzog, E. D., Battelle, B-A., Kass, L., Renninger, G. H. \& Chamberlain, S. C. Morphology of the eye of the hydrothermal vent shrimp, Alvinocaris markensis

Norman, M. D. \& Lu, C. C. Redescription of the southern dumpling squid Euprymna tasmanica and a revision of the genus Euprymna (Cephalopoda: Sepiolidae)

Weber, L. I., Gray, D. R., Hodgson, A. N. \& Hawkins, S. J. Genetic divergence between South African Helcion species and north-east Atlantic H. pellucidum (Mollusca: Patellogastropoda)

Service, M. \& Magorrian, B. H. The extent and temporal variation of disturbance to epibenthic communities in Strangford Lough, Northern Ireland

Thiébaut, E., Cabioch, L., Dauvin, J.-C., Retière, C. \& Gentil, F. Spatio-temporal persistence of the Abra alba - Pectinaria koreni muddy-fine sand community of the eastern Bay of Seine 